\title{
Preservation of the gene fund and increasing the livestock productivity of the White-headed Ukrainian breed
}

\author{
Voitenko S. ${ }^{1}$, Sydorenko O. ${ }^{2}$ \\ Institute of Animals Breeding and Genetics named after M.V. Zubets of NAAS \\ 1, Pohrebniaka Str., Chubynske village, Boryspil district, Kyiv, Ukraine, 08321 \\ e-mail: 1slvoitenko@ukr.net, ${ }^{2}$ sydorenkoolena@ukr.net \\ ORCID: ${ }^{10000-0003-3530-6360, ~}{ }^{20000-0003-2429-9361 ~}$
}

\begin{abstract}
Goal. To determine the level of homozygosity of the active part of the population of the White-headed Ukrainian breed for one generation and 50 years of reproduction, as well as the possibility of using inbreeding to preserve the gene pool of the breed and increase animal productivity. Methods. The study was conducted on animals of the White-headed Ukrainian breed, divided into outbred and inbred. The first series of experiments determined the influence of unrelated and related selections of parental pairs, the second series studied the influence of the origin of the bull (the father of the offspring) on the manifestation of signs of productivity in outbred and inbred cattle. In both experiments, the group of in-bred included animals whose inbreeding coefficient was $\mathrm{Fx}=0.39-29.7 \%$, and the group of outbred - who had no common ancestors in the pedigrees. In the third series of experiments, the influence of different degrees of inbreeding (moderate, close, and very close) on the milk productivity of cows of a specific origin was determined, for which the descendants of the bull Zlak's UA 673 were divided into 4 groups. Live weight of cows, milk yield for lactation, content and amount of milk fat in milk, age of the 1st insemination were determined. The level of inbreeding growth was calculated for one generation and 50 years of reproduction. Results. The advantage of inbred heifers in live weight in different growing periods compared to outbred individuals was established, especially at the final stage, which accelerated their physiological and economic maturity. The effect of inbreeding on the reduction of milk production in cows of individual bulls without statistically significant difference with outbred animals had been proved. There was a direct, medium and weak connection between milk yield during the 1st lactation with age and live weight at the 1st insemination. It was proved that the increase of the inbreeding coefficient from $\mathrm{Fx}=0.78-2.93 \%$ to $\mathrm{Fx}=$ $12.5-29.7 \%$ in the daughter offspring of the bull Zlak's UA 673 significantly increased milk productivity for $1-2$ lactations. It was found that in the modern, active part of the population of the White-headed Ukrainian breed, inbreeding can increase by $1.68 \%$ in a generation, and by $16.5 \%$ in 50 years of reproduction. Conclusions. When breeding White-headed Ukrainian cattle, which currently has 300 cows and 11 bulls, it is impossible to avoid a related selection of parent pairs. With this in mind, inbreeding can be used as a method of preserving the gene pool of White-headed Ukrainian breed in the context of preserving the biodiversity of wildlife. The use of close inbreeding is preferable to moderate and close.
\end{abstract}

Key words: cattle, inbreeding, outbreeding, inbreeding coefficient, biodiversity.

DOI: https://doi.org/10.31073/agrovisnyk202102-06

One of the domestic populations, as an object of local, local genetic resources in Ukraine, was created in the late eighteenth century. White-headed Ukrainian breed of cattle with its adaptation to the natural and climatic conditions of the Polissya zone, high payment for milk feed, resistance, unpretentiousness to feeding [1]. However, even at the beginning of its existence and now, due to the insufficient number of livestock to produce the next generation of cattle, it is impossible to avoid mating animals that have common ancestors in pedigrees. Many researchers believe that this approach does not always contribute to high productivity of animals, although it protects the population from extinction [2, 3]. Currently, all White-headed Ukrainian cattle are kept in only one breeding farm, which has 300 females (cows) of the active part of the population. The semen of 11 bulls is concentrated in the breeding enterprises of Ukraine, but all of them were used to reproduce the breeding stock of cows in this herd. Therefore, for this breed it is very important to find leverage to preserve its gene pool, in particular the use of related breeding.

Scientists have shown that in a population of 1,000 females and above (under panmixia), the inbreeding rate increases by about $0.13 \%$ per generation. But reducing its number to 500 or 250 females at a sex ratio of 1:10 leads to a doubling of inbreeding with the possibility of inbred depression. At the same time, the use of line crosses in gene pool populations for $20-30 \%$ of animals will help to reduce inbreeding by half [4].

Negative consequences of related breeding can be avoided if the parent pairs are selected not according to the degree of inbreeding, but according to their individual compatibility. It is proved that the most undesirable from the standpoint of inbred depression is inbreeding in several generations and complex. Incest is permissible only in the presence of high economically useful traits in mating parents [5].

Inbreeding from the point of view of genetics is the crossing of organisms that have common ancestors. In animal husbandry practice, inbreeding is a form of selection for mating animals that have common 
ancestors in the pedigree. It is used to obtain organisms homozygous for many alleles, to preserve alleles in the population that determine the desired traits, and to detect hereditary pathology. Without this method, there is no breeding of new or improvement of existing breeds of farm animals, especially given the continuous process of improving their productive qualities. The intensification of the livestock industry in recent years and the involvement of only a few breeds of farm animals in the production process raises concerns in the world community about the rate of extinction of species, breeds and populations that play an important role in addressing food security, especially local populations gene complexes [6, 7].

The need to monitor the influence of the level and degree of inbreeding on the main economic means of dairy cattle, as well as the expediency of rigid selection of individuals who have defects of the constitution and exterior are proved. [2, 8].

The negative role of inbreeding, especially close and close degrees, in reducing the milk productivity of animals and their reproductive capacity has been clarified [9-12]. In addition to the negative impact of inbreeding on the productive qualities of animals, it can lead to genetic imbalance in the population, the emergence of lethal genes and organisms with various recessive hereditary abnormalities that do not manifest in heterozygotes. Researchers emphasize the inexpediency of using high-grade inbreeding [1315].

Given that the genotype interacts with environmental factors in the formation of a new organism, scientists have proven the role of breed, duration of work with it, housing conditions, feeding level, etc., which in sum with the type of parental pairs and the degree of inbreeding. The need to predict the increase of homozygosity in generations and all possible levers to prevent the inevitable manifestation of inbred depression was recognized [16, 17].

The main method of breeding white-headed cattle of the Ukrainian breed, which is currently not commercial and belongs to the disappearing domestic populations, is considered to be purebred, with the possibility to use inbreeding along with outbreeding. Breeding of White-headed Ukrainian cattle breed should be carried out on a scientific basis in the context of conservation of biodiversity of fauna. With this in mind, it is necessary to find the degree of "available" related breeding, which will allow to preserve the biological characteristics of the breed and its genetic variability, will not lead to a significant decrease in productivity and the emergence of recessive lethal mutations.

Given this, it is obvious to determine the theoretically motivated level of inbreeding of White-headed Ukrainian breed, the impact of inbreeding on the phenotypic manifestation of breeding traits and the feasibility of obtaining and using inbred females to preserve the gene pool of this unique population in the context of wildlife biodiversity.

The purpose of the research is to determine the level of homozygosity of the active part of the population of the White-headed Ukrainian breed for one generation and 50 years of reproduction, as well as the possibility of inbreeding to preserve the gene pool of the breed and increase animal productivity.

Material and methods of research. The material for the research was cattle of the White-headed Ukrainian breed in LLC "Podilsky Gospodar" of Khmelnytsky Region, which in the I series of experiments was divided into 2 groups without taking into account the origin: Group I - outbred animals (no common ancestors in the pedigree); Group II - inbred (inbreeding coefficient Fx $=0.39-29.7 \%$ ). In the second series of experiments, the animals were divided into the same 2 groups, but their origin was taken into account by the bull - the offspring father. The phenotypic manifestation of traits in cows, daughters of breeding bulls Zlak's UA673 and Nickel's UA6800410641, which belonged to the Mart's line, was studied; Plius's UA 629 and Som's UA6800085660 - Ozon's line. To determine the effect of different degrees of inbreeding on economically useful traits of cows of specific origin, investigated the productivity of the offspring of the bull Zlak's UA 673, dividing them into 4 groups: group I - outbred, group II - inbred, inbreeding rate Fx $=0.78-$ $2.93 \%$ (moderate degree of inbreeding); group III - Fx $=3.13-11.72 \%$ (near) and group IV $-\mathrm{Fx}=12.5-$ $29.7 \%$ (close). Among the offspring of this bull there are no inbred animals of remote degree, so the group with such a degree of inbreeding in the study was not.

The degree of inbreeding was determined by the Shaporuzh method, and the inbreeding coefficient (Fx) was determined by the Wright - Kislovskii's formula [18].

The forecast of growth of the level of inbreeding in this herd is made according to the method of assessing the state of the population and the genetic risk of its loss, proposed by the European Livestock Association [19].

Live weight of animals was determined by weighing in predetermined age periods. The yield of cows for 305 days of lactation, fat content and the amount of milk fat in milk, the age of their 1st insemination were determined using materials from the database of the dairy herd management system ("Intesel-Orsek" as of January 1, 2018).

Statistical processing of research materials was done using the software package "STATISTICA 10.0" on a PC [20].

Research results and their discussion. It was found that in a population of 11 males and 300 females, namely the number of animals currently active in the White-headed Ukrainian breed, inbreeding may increase by $1.68 \%$ in one generation, and by $16.5 \%$ in 50 years of reproduction. However, the herd of this breed already has more than $50 \%$ of inbred cows, although bulls, whose semen is stored at breeding enterprises in Ukraine, are outbred. Given the forecast for the growth of inbreeding in the herd, the number 
of homozygous animals will only increase. This suggests the need to determine the optimal degree of inbreeding to avoid inbred depression. Our vision is consistent with the opinion of other researchers, according to which due to the increase in the degree of homozygosity by $1 \%$ decreases yield, the yield of milk fat and protein, prolongs the service period, increases the number of heavy calves, etc. [21, 22].

According to research, a certain variability in the dynamics of live weight of outbred and inbred heifers of White-headed Ukrainian breed (Table 1). The most noticeable and stable advantage in live weight at all ages was found in the group of inbred animals, although without a statistically significant difference relative to outbreds.

\section{Live weight and age of first insemination of heifers $(M \pm m)$}

\begin{tabular}{|l|c|c|c|c|}
\hline \multirow{2}{*}{ Indicators } & \multicolumn{4}{|c|}{ Experimental group } \\
\cline { 2 - 5 } & $\mathrm{I}$ (outbred) $(\mathrm{n}=127)$ & $\mathrm{II}$ (inbred) $(\mathrm{n}=155)$ \\
\cline { 2 - 5 } & $\mathrm{M} \pm \mathrm{m}$ & $\mathrm{Cv}, \%$ & $\mathrm{M} \pm \mathrm{m}$ & $\mathrm{Cv}, \%$ \\
\hline Live weight, kg: & $29,9 \pm 0,69$ & 14,86 & $30,9 \pm 0,45$ & 12,55 \\
\hline at birth & $130,7 \pm 2,61$ & 14,65 & $134,3 \pm 2,21$ & 16,46 \\
\hline in 6 months & $234,1 \pm 4,71$ & 14,92 & $237,7 \pm 4,12$ & 17,41 \\
\hline at 12 months & $321,9 \pm 5,23$ & 11,94 & $332,7 \pm 4,83$ & 14,54 \\
\hline at 18 months & $343,3 \pm 6,62$ & 14,04 & $350,4 \pm 4,81$ & 13,65 \\
\hline at the 1st insemination & $20,5 \pm 0,47$ & 25,98 & $19,2 \pm 0,36$ & 23,23 \\
\hline Age of 1st insemination, month &
\end{tabular}

The insignificant difference between the live weight of outbred and inbred heifers at birth $(1 \mathrm{~kg})$ indicates that during the embryonic period of ontogenetic development of the animal the formation of a homozygous organism occurred without much disruption of organs and tissues, which would further lead to lower live weight or individuals with hereditary anomalies. The advantage of inbred heifers over outbred heifers in live weight during the period of their growth for 3-18 months ranged from 3.6 to $10.8 \mathrm{~kg}$. During the whole growing period, the increase in live weight of inbred heifers was $301.8 \mathrm{~kg}$, which is $9.8 \mathrm{~kg}$ more than outbred ones. It is concluded that the genotype of inbred heifers is somewhat better adapted to environmental conditions than outbred.

Higher live weight of inbred heifers in the studied periods of growth, especially at the final stage, led to an earlier, compared with outbred, physiological and economic ability and, consequently, earlier (1.3 months) age of 1 st insemination, and therefore, and milk production. However, the difference between animals of different groups is statistically insignificant.

The obtained research results are consistent with the studies of other authors, who proved the lack of negative effects of inbreeding on live weight of cows [23].

The coefficients of variation of live weight of heifers from birth to 18 months of age in outbred heifers were in the range of $11.94-14.94 \%$, and inbred $-12.55-17.41 \%$, respectively, in accordance with the average degree of variability of traits. Almost identical indicators of phenotypic variability of live weight of outbred and inbred heifers indicate the absence of negative effects of inbreeding, because in both groups individuals are unequal and have a similar deviation from the mean. This confirms that the herd does not use selection pressure and stabilization selection, the use of which would reduce the genetic variability of the gene pool of the population. The phenotypic variability of the age of first insemination in animals of both groups was even more pronounced, which, in fact, is positive for maintaining the genetic variability of a small population.

Given the regularity of the irreversibility of the ontogenetic development of animals, it was logical to find a connection between the live weight of outbred and inbred heifers at birth with their live weight in different periods of rearing and at 1 st insemination, as well as with the age of first insemination. Live weight of cattle in ontogenesis is determined mainly by environmental factors, but due to genotype due to birth, so it is believed that individuals with higher live weight at birth for creating appropriate growing conditions have a higher live weight gain and are more involved in reproduction than low weight.

Using correlation analysis, insignificant and statistically insignificant correlation coefficients of live weight of calves at birth with their live weight at the age of 6,12 and 18 months were established and at the 1st insemination, as well as with the age of the 1st insemination. The exception was the association of live weight of inbred heifers at birth with their live weight at 12 months of age. $(r=+0.266, P<0.05)$ (Table 2).

\section{Correlation coefficient between live weight of outbred and inbred heifers in different age} periods $(r \pm m r)$

\begin{tabular}{|l|c|c|}
\hline \multirow{2}{*}{ Combined features } & \multicolumn{2}{|c|}{ Experimental group } \\
\cline { 2 - 3 } & \multicolumn{2}{|c|}{ I (outbred) } \\
\hline Live weight at birth and: & $0,228 \pm 0,135$ & $0,226 \pm 0,134$ \\
\hline$-\quad$ in 6 months & $0,008 \pm 0,139$ & $0,266 \pm 0,136^{*}$ \\
\hline
\end{tabular}




\begin{tabular}{|ll|l|l|}
\hline- & at 18 months & $0,097 \pm 0,138$ & $0,148 \pm 0,139$ \\
\hline- & at the 1st insemination & $0,018 \pm 0,139$ & $-0,161 \pm 0,081$ \\
\hline- & age of 1st insemination & $0,007 \pm 0,139$ & $-0,039 \pm 0,118$ \\
\hline
\end{tabular}

${ }^{*} p<0,05$.

With this in mind, it was concluded that in the herd of White-headed Ukrainian breed among outbred and inbred heifers selection for live weight at birth will not significantly improve the characteristics in other periods of growth, in particular the age of 1 st insemination. Similar results were obtained by other researchers $[24,25]$.

Dairy productivity, which is the main breeding trait and purpose of economic use of dairy and dairy cattle, needs to be constantly improved by any means. This issue is also relevant for the White-headed Ukrainian breed, which, although not a commercial breed, is the object of milk production.

A comparative analysis of milk productivity of White-headed Ukrainian cows for 305 days of 1-4 lactations showed the opposite tendency to live weight of the advantage of outbred animals over inbred ones, although without a statistically significant difference between groups. The advantage of outbred cows over inbred ones was established, which was $207 \mathrm{~kg}$ for the 1 st lactation, $42 \mathrm{~kg}$ for the 2 nd lactation and $10 \mathrm{~kg}$ for the 3rd lactation, and only for the 4th lactation outbred cows lost $131 \mathrm{~kg}$ to inbred cows (Table 3).

\section{Dairy productivity of cows $(M \pm m)$}

\begin{tabular}{|c|c|c|c|c|c|c|}
\hline \multirow{3}{*}{ Indicators } & \multicolumn{6}{|c|}{ Experimental group } \\
\hline & \multicolumn{3}{|c|}{ I (outbred) $(\mathrm{n}=127)$} & \multicolumn{3}{|c|}{$\|$ (inbred) $(n=155)$} \\
\hline & $\mathrm{n}$ & $M \pm m$ & $\mathrm{Cv}, \%$ & $\mathrm{n}$ & $M \pm m$ & $\mathrm{Cv}, \%$ \\
\hline \multicolumn{7}{|c|}{ 1st lactation } \\
\hline Yield, kg & \multirow[t]{3}{*}{127} & $4327 \pm 76,01$ & 19,79 & \multirow[t]{3}{*}{155} & $4120 \pm 68,36$ & 20,66 \\
\hline The fat content in milk, $\%$ & & $3,43 \pm 0,071$ & 24,37 & & $3,56 \pm 0,026$ & 8,54 \\
\hline Milk fat, kg & & $148,2 \pm 4,04$ & 30,72 & & $147,5 \pm 2,73$ & 23,08 \\
\hline & \multicolumn{6}{|c|}{ 2nd lactation } \\
\hline Yield, kg & \multirow[t]{3}{*}{78} & $4604 \pm 119,79$ & 22,98 & \multirow{3}{*}{98} & $4562 \pm 103,23$ & 22,40 \\
\hline The fat content in milk, $\%$ & & $3,65 \pm 0,012$ & 2,65 & & $3,71 \pm 0,011$ & 2,96 \\
\hline Milk fat, kg & & $168,7 \pm 4,65$ & 24,35 & & $168,9 \pm 4,16$ & 24,36 \\
\hline & \multicolumn{6}{|c|}{$\begin{array}{l}108,1 \pm 4,65 \\
\text { 3rd lactation }\end{array}$} \\
\hline Yield, kg & \multirow[t]{3}{*}{35} & $4780 \pm 169,32$ & 20,95 & \multirow[t]{3}{*}{31} & $4770 \pm 204,38$ & 23,85 \\
\hline The fat content in milk,\% & & $3,68 \pm 0,018$ & 2,88 & & $3,63 \pm 0,021$ & 3,24 \\
\hline Milk fat, kg & & $175,7 \pm 6,15$ & 20,73 & & $173,1 \pm 7,64$ & 24,57 \\
\hline & \multicolumn{6}{|c|}{ 4th lactation } \\
\hline Yield, kg & \multirow[t]{3}{*}{17} & $4456 \pm 192,39$ & 17,81 & \multirow[t]{3}{*}{15} & $4587 \pm 211,86$ & 17,89 \\
\hline The fat content in milk,\% & & $3,72 \pm 0,027$ & 2,95 & & $3,64 \pm 0,035$ & 3,72 \\
\hline Milk fat, kg & & $166,0 \pm 7,61$ & 18,89 & & $167,7 \pm 8,55$ & 19,75 \\
\hline
\end{tabular}

The fat content of milk did not have a clear relationship with inbreeding and milking and did not agree with the claim of many researchers that an increase in milk yield is accompanied by a decrease in fat content in milk due to the antagonistic nature of these symptoms [26]. A similar trend was found for the amount of milk fat in the milk of cows of different homozygosity.

Coefficients of variation in milk productivity, in addition to the fat content in milk, indicate the possibility of forming groups of highly productive outbred and inbred cows, although such a selection measure may lead to a narrowing of genetic variability in a small population. Therefore, in the herd it is desirable not to carry out strict selection of females for milking.

There is a tendency to a direct relationship in outbred $(r=0.424 \pm 0.081 ; r=0.370 \pm 0.083)$ and inbred $(r=0.166 \pm 0.079 ; r=0.019 \pm 0.081)$ cows between milking for the first lactation and the age of the first insemination, as well as live weight at the 1st insemination (Table 4). In outbred cows, this connection was of medium strength, and in inbred - weak.

\section{Correlation coefficient between yield for the 1st lactation with indicators of reproductive capacity and signs of milk productivity $(r \pm m r)$}

\begin{tabular}{|l|l|l|}
\hline \multicolumn{2}{|c|}{ Combined features } & \multicolumn{2}{c|}{ Experimental group } \\
\cline { 2 - 3 } & \multicolumn{1}{|c|}{$\mathrm{I}$ (outbred) } & II (inbred) \\
\hline Yield for the first lactation and: & $0,424 \pm 0,081$ & $0,166 \pm 0,079$ \\
\hline age of the 1st insemination & $0,370 \pm 0,083$ & $0,019 \pm 0,081$ \\
\hline live weight at the 1st insemination & $-0,074 \pm 0,089$ & $0,024 \pm 0,080$ \\
\hline fat content in milk & $0,443 \pm 0,080^{* * *}$ & $0,989 \pm 0,012^{* *}$ \\
\hline Yield for the second lactation - the fat content in milk
\end{tabular}




\begin{tabular}{|l|l|l|}
\hline Yield for the 3rd lactation - the fat content in milk & $-0,128 \pm 0,089$ & $0,171 \pm 0,079$ \\
\hline Yield for the 4th lactation - the fat content in milk & $0,363 \pm 0,083$ & $0,577 \pm 0,066$ \\
\hline${ }^{* \star} \mathrm{p}<0,01 ;{ }^{* \star *} \mathrm{p}<0,001$.
\end{tabular}

Relationships between 1st and 3rd lactation milk yield with milk fat content were very low and varied in experimental cows. Only the relative variability of milk yield of cows during the 2 nd lactation with the fat content in milk was reliable, and in inbred cows the correlation coefficient indicated a strong relationship ( $r$ $=0.989 \pm 0.012)$ between traits, in outbred - about the average $(r=0.443 \pm 0.080)$. A similar trend was found for the association of milk yield during the 4th lactation with fat content, but without a statistically significant difference.

According to the determined productivity of inbred animals in the herd, it is not possible to clearly determine what happens to animals of a specific genealogical formation or origin. Given the point of view of many researchers on the significant impact on the economic useful traits of cows of paternal origin [27, 28], we studied the milk productivity of outbred and inbred cows, which were daughters of bulls Zlak's UA 673 and Nickel UA 6800410641 (Mart's line), Plius's UA 629 and Som's UA 6800085660 (Ozon's line) for the 1 st and 2nd lactation.

The results of studies show that inbreeding affects the reduction of milk productivity in the offspring of all studied bulls without a statistically significant difference with outbreds of the same origin (Table 5). The negative effect of inbreeding among the offspring of the bull Zlak's UA 673 was manifested in a decrease in milk yield for the first lactation by $477 \mathrm{~kg}$ and milk fat - by $16.7 \mathrm{~kg}$, and for the 2nd lactation - by $853 \mathrm{~kg}$ and $34.3 \mathrm{~kg}$, respectively.

Inbred cows, daughters of the bull Nickel's UA 6800410641 were inferior to outbreds in milking for the 1st lactation by $460 \mathrm{~kg}$, for the 2nd - by $384 \mathrm{~kg}$, for milk fat - by 21.1 and $12.5 \mathrm{~kg}$, respectively.

Bull Plius UA 629 increased milk yield in outbred daughters, compared to inbred, for the 1st and 2nd lactation by $62 \mathrm{~kg}$ and $667 \mathrm{~kg}$, respectively. In outbred cows, the milk was fatter.

A similar trend of advantage in milk productivity of outbred cows over inbred cows is characteristic for the daughters of the bull Som's UA 6800085660.

According to the determined coefficients of variation of milk productivity indicators, the non-consolidation of selection groups of both outbred and inbred cows, daughters of the same father, has been proved. Significant deviations of milk yield and milk fat from the average value for each brood were revealed with the possibility of their improvement due to selection.

5. Dairy productivity of cows, daughters of individual bulls $(M \pm m)$

\begin{tabular}{|c|c|c|c|c|c|c|}
\hline \multirow[t]{3}{*}{ Indicator } & \multicolumn{6}{|c|}{ Experimental group } \\
\hline & \multicolumn{3}{|c|}{ I (outbred) } & \multicolumn{3}{|c|}{ II (inbred) } \\
\hline & $\mathrm{n}$ & $\mathrm{M} \pm \mathrm{m}$ & $\mathrm{Cv}, \%$ & $\mathrm{n}$ & $\mathrm{M} \pm \mathrm{m}$ & $\mathrm{Cv}, \%$ \\
\hline \multicolumn{7}{|c|}{ Zlak UA 673} \\
\hline Yield for the 1st lactation, $\mathrm{kg}$ & \multirow[t]{2}{*}{17} & $4643 \pm 126,66$ & 20,12 & \multirow[t]{2}{*}{63} & $4166 \pm 138,47$ & 26,38 \\
\hline Milk fat for the 1st lactation, $\mathrm{kg}$ & & $166,8 \pm 8,14$ & 20,14 & & $150,1 \pm 5,14$ & 27,22 \\
\hline Yield for the 2nd lactation, $\mathrm{kg}$ & \multirow[t]{2}{*}{14} & $5307 \pm 247,13$ & 17,42 & \multirow[t]{2}{*}{44} & $4454 \pm 257,75$ & 37,95 \\
\hline Milk fat for the 2nd lactation, $\mathrm{kg}$ & & $197,9 \pm 10,49$ & 19,83 & & $163,6 \pm 10,48$ & 42,47 \\
\hline \multicolumn{7}{|c|}{ Nikel UA 6800410641} \\
\hline Yield for the 1st lactation, $\mathrm{kg}$ & \multirow[t]{2}{*}{62} & $4154 \pm 133,07$ & 25,23 & \multirow[t]{2}{*}{60} & $3694 \pm 115,31$ & 24,18 \\
\hline Milk fat for the 1st lactation, $\mathrm{kg}$ & & $151,3 \pm 5,09$ & 26,05 & & $130,2 \pm 4,93$ & 29,34 \\
\hline Yield for the 2nd lactation, $\mathrm{kg}$ & \multirow[t]{2}{*}{24} & $4249 \pm 230,52$ & 26,58 & \multirow[t]{2}{*}{31} & $3865 \pm 186,67$ & 22,89 \\
\hline Milk fat for the 2nd lactation, $\mathrm{kg}$ & & $155,8 \pm 8,81$ & 27,68 & & $143,3 \pm 7,19$ & 27,96 \\
\hline \multicolumn{7}{|c|}{ Plius UA 629} \\
\hline Yield for the 1st lactation, $\mathrm{kg}$ & \multirow[t]{2}{*}{11} & $4126 \pm 136,91$ & 11,04 & \multirow[t]{2}{*}{46} & $4064 \pm 132,64$ & 22,12 \\
\hline Milk fat for the 1st lactation, $\mathrm{kg}$ & & $149,9 \pm 5,06$ & 11,02 & & $147,8 \pm 4,87$ & 22,14 \\
\hline Yield for the 2nd lactation, $\mathrm{kg}$ & 10 & $5016 \pm 273,32$ & 17,23 & \multirow[t]{2}{*}{38} & $4349 \pm 191,79$ & 27,18 \\
\hline Milk fat for the 2nd lactation, $\mathrm{kg}$ & & $185,4 \pm 10,58$ & 25,17 & & $160,2 \pm 7,42$ & 28,55 \\
\hline \multicolumn{7}{|c|}{ Som UA 6800085660} \\
\hline Yield for the 1st lactation, $\mathrm{kg}$ & \multirow[t]{2}{*}{93} & $4072 \pm 84,08$ & 19,91 & \multirow[t]{2}{*}{32} & $3986 \pm 145,15$ & 20,61 \\
\hline Milk fat for the 1st lactation, $\mathrm{kg}$ & & $148,2 \pm 3,07$ & 19,97 & & $145,4 \pm 5,44$ & 21,18 \\
\hline Yield for the 2nd lactation, $\mathrm{kg}$ & \multirow[t]{2}{*}{71} & $4333 \pm 102,68$ & 19,96 & \multirow[t]{2}{*}{24} & $4049 \pm 204,66$ & 24,76 \\
\hline Milk fat for the 2nd lactation, kg & & $158,1 \pm 3,95$ & 21,05 & & $147,7 \pm 7,64$ & 25,38 \\
\hline
\end{tabular}

Analysis of inbred animals in comparison with outbred animals in general by herd, as well as by specific offspring, although it gives an idea of the advantages of unrelated selection of parental pairs over related to obtain individuals of the next generation, but does not allow to determine which approaches to animals if they are already homozygous. With this in mind, the influence of increasing homozygosity (inbreeding coefficient) on the main functional features of milk productivity cows of White-headed Ukrainian breed daughters of the bull Zlak's UA673 was determined. 
It was found that the daughter offspring of the bull Zlak's UA 673 with increasing coefficient of inbreeding significantly increases milk productivity (Table 6). Thus, for the 1st lactation of cows of moderate degree of inbreeding ( $F x=0.78-2.93 \%)$ were inferior to milking individuals of close degree ( $F x=3.13-11.72 \%)$ by $132 \mathrm{~kg}$ and close ( $F x=12,5-29.7 \%)$ - at $318 \mathrm{~kg}$. There was a similar trend with milk fat.

\section{Dairy productivity of cows-daughters of bull Zlak's UA673 depending on the degree of inbreeding $(M \pm m)$}

\begin{tabular}{|c|c|c|c|c|}
\hline Indicator & Outbreeding & \multicolumn{3}{|c|}{ Degree (coefficient) of inbreeding } \\
\cline { 3 - 5 } & & $\begin{array}{c}\text { moderate } \\
\left(F_{x}=0,78-2,93 \%\right)\end{array}$ & $\begin{array}{c}\text { near }\left(F_{x}=3,13-\right. \\
11,72 \%)\end{array}$ & $\begin{array}{l}\text { close }\left(F_{x}=12,5-\right. \\
29,7 \%)\end{array}$ \\
\hline \multicolumn{5}{|c|}{1 st lactation } \\
\hline Yield, kg & $4643 \pm 126,66$ & 17 & 26 & 15 \\
\hline Milk fat, kg & $166,8 \pm 8,14$ & $1497 \pm 164,2$ & $4229 \pm 77,03$ & $4415 \pm 268,46$ \\
\hline \multicolumn{5}{|c|}{2 2nd lactation } \\
\hline $\mathrm{n}$ & 14 & 8 & $159,1 \pm 6,08$ & $163,1 \pm 10,02$ \\
\hline Yield, kg & $5307 \pm 247,13$ & $4810 \pm 160,34$ & $4911 \pm 172,13$ & $5106 \pm 222,48$ \\
\hline Milk fat, kg & $197,9 \pm 10,49$ & $177,0 \pm 6,95$ & $182,3 \pm 6,64$ & $189,5 \pm 9,17$ \\
\hline
\end{tabular}

At the same time, inbred cows produced 228-546 kg less milk during the first lactation than outbred cows without a statistically significant difference between them. Among inbred cows, the highest milk productivity in the $1 \mathrm{st}$ and 2 nd lactations was in individuals of close degree $(F x=12.5-29.7 \%)$. Similar results were obtained in cattle of red steppe breed, where cows of groups of close and moderate degrees of inbreeding predominated outbred cows in milkings of the 1st and 3rd lactations, with the highest yield for the 1st lactation were in cows of close inbreeding [3]. However, this contradicts the data of other researchers, who prove the negative impact of inbreeding of a close degree on the manifestation of the main selection traits of cattle [12, 29, 30].

The advantage of cows of close degree of inbreeding ( $F x=12.5-29.7 \%)$ over the representatives of moderate and close feet in terms of milk yield was preserved during the second lactation and amounted to $296 \mathrm{~kg}$ and $195 \mathrm{~kg}$, respectively. We proved that cows with a lower inbreeding rate, compared to close, had lower milk productivity. Thus, from individuals whose inbreeding coefficient $\mathrm{Fx}=0.78-2.93 \%$ (moderate degree) for the 2nd lactation received $296 \mathrm{~kg}$ less milk than with the inbreeding coefficient $F x=12.5-29.7 \%$ (close degree). However, cows of varying degrees of inbreeding, including close, were inferior in milk productivity for the second lactation to outbred animals, although without a statistically significant difference. That is, if you choose the milk productivity between the outbred and inbred daughters of the bull Zlak's UA 673 , preference should be given to outbreds obtained by unrelated selection of parent pairs. But the herd already uses homozygous individuals of close inbreeding and their subsequent receipt is inevitable given the minimal number of breeds. The right opinion was expressed by the authors of the created breeds [31, 32], who recommend when obtaining offspring with such a level of homozygosity to abandon mating females with a brood, which may be their father or brother, are lethal genes or associated with a number of diseases.

In general, when working with the White-headed Ukrainian breed, the active part of which has 300 cows, it is impossible to avoid intra-breed selection of related animals, especially since the population already uses animals with a fairly high ancestral heredity, especially bulls. Although there is an increase in homozygosity in the breed, it does not yet lead to inbred depression, given the theoretically calculated level of inbreeding increase by $1.68 \%$ per generation. In addition, a fairly high coefficient of variability of all studied traits indicates the relative plasticity of the breed and the specificity of individual groups associated with a common origin.

We believe that in order to preserve the livestock of White-headed Ukrainian breed, along with outbreeding, it is possible to use inbreeding of moderate and close degrees, as well as close. Methods of selection and breeding work in the herd of this cattle are not aimed at the consolidation of animals of the same origin or linear affiliation on the main selection characteristics, but on the contrary - to maintain sufficient variability in the breed. The use of close inbreeding in breeding White-headed Ukrainian breed is consistent with the point of view of the classic zootechnics D.A. Kyslovskii, who believed that the growth of homozygosity does not consolidate animals, but rather divides their genotype into individual homozygous combinations that do not have significant similarity to heredity [33]. However, this contradicts the statements of other authors, who believe that with close inbreeding, heredity is significantly reduced, and consolidation is increased [34, 35].

Thus, the phenotypic manifestation of economically useful traits of inbred White-headed Ukrainian cattle and the lack of a statistically significant difference with outbred animals does not give grounds to abandon the use of the inbreeding method in breeding White-headed Ukrainian cattle. 


\section{Conclusions}

The presence of more than $50 \%$ of inbred individuals among the active part of White-headed Ukrainian cows and the calculated theoretical level of increase of population homozygosity for one generation, which is $1.68 \%$, testify to the impossibility of avoiding related breeding in the selection of parent pairs. The influence of inbreeding of different degrees really leads to a decrease in milk productivity of cows, compared with outbred, but high coefficients of variation of productivity traits confirm sufficient genetic variability of breeding groups and the ability to select the desired traits. Close inbreeding does not lead to inbreeding depression and a significant reduction in the main breeding traits of cattle and is more desirable compared to moderate and close variants. In general, inbreeding, including the close degree, can be used as a method of preserving the gene pool of cattle of a unique, small White-headed Ukrainian breed in the context of preserving the biodiversity of the animal world.

\section{References}

1. Voitenko, S.L., \& Vyshnevskyi, L.V. (2016). Biloholova ukrainska poroda v istorychnomu aspekti Ukrainian [Whitehead breed in historical perspective]. Bulletin of Sumy National Agrarian University, 7(30), 51-57. [In Ukrainian].

2. Zvereva, E.A., \& Muraveva, N.A. (2016). Effektivnost primeneniya inbridinga pri razvedenii korov yaroslavskoy porody [The effectiveness of the use of inbreeding in the breeding of cows of the Yaroslavl breed]. International Research Journal, 11(53), 5, 18-21. doi: 10.18454/IRJ.2016.53.121. [In Russian].

3. Mykytas, R.Ye., Demchuk, V.V., \& Papakina, N. S. (2001). Prohnozuvannia molochnoi produktyvnosti koriv chervonoi stepovoi porody riznoho stupenia inbrydynhu [Prediction of milk productivity of cows of Red Steppe breed of different degree of inbreeding]. Taurida Scientific Herald, 17, 59 - 62. [In Ukrainian].

4. Kuznetcov, V.M. (2005). Imitatsionnoe modelirovanie lineynogo razvedeniya $v$ genofondovykh populyatsiyakh [Simulation modeling of linear breeding in gene pool populations]. Russian Agricultural Sciences, 6, 37- 40. [In Russian].

5. Shendakov, A.I., Khanina, T.I., \& Shendakova, T.A. (2016). Minimizatsiya inbrednoy depressii po zhivoy masse u simmentalskogo molodnyaka [Minimization of inbreeding depression on live body weight of Simmental calves]. Zootechniya, 4, 5- 8. [In Russian].

6. Preparation of national strategies and action plans for animal genetic resources. (2009). FAO Animal Production and Health Guidelines, Rome, 2, 71.

7. Biodiversity for Food and Agriculture (2011). Contributing to food security and sustainability in a changing world. Outcomes of an Expert Workshop Held by FAO and the Platform on Agrobiodiversity Research from 14-16 April 2010 in Rome, Italy: FAO of the UN and PAR.

8. Liubimov, A.I., \& ludin, V.M. (2014). Kompleksnyy podkhod k tselenapravlennomu zakrepleniyu inbridinga [Integrated approach to the purposefull fixation of inbreeding]. Zootechniya, 4, 2- 4. [In Russian].

9. Guba, S., \& Wolf G. (1984). [Changes in some standard characteristics of cattle in response to various extents of inbreeding]. ActaAgron. Acad. Scient. Hungar., 1-2, 67-95.

10. Dezetter, C., Leclerc, H., Mattalia, S., Barbat, A., Boichard, D., \& Ducrocq, V. (2015). Inbreeding and crossbreeding parameters for production and fertility traits in Holstein. Montbéliarde, and Normande cows. Journal of Dairy Science, 98(7), 4904-4913. doi: 10.3168/jds.2014-8386.

10. Pryce, J. E., Haile-Mariam, M., Goddard, M. E., \& Hayes, B. J. (2014). Identification of genomic regions associated within breeding depression in Holstein and Jersey dairy cattle. Genet. Sel. Evol., 46(1). doi: 10.1186/s12711-014-0071-7.

11. Nadashkovskii, I.S., Sermiagin, A.A., Bogdanova, T.V., Ermilov, A.N., lanchukov, I.N., \& Zinoveva, N.A. (2018). Otsenka vliyaniya urovnya inbridinga na molochnuyu produktivnost i vosproizvoditelnye kachestva korov golshtinizirovannoy populyatsii cherno-pestroy porody [Evaluation of inbreeding effect for milk production and fertility traits Black-and-White cattle improved by Holstein breed]. Dairy and Beef Cattle Farming, 7, 17-22. doi: 10.25632/MMS.2018.7.21450. [In Russian].

12. Croquet, C., Mayeres, P., Gillon, A., Vanderick, S., \& Gengler, N. (2006). [Inbreeding depression for global and partial economic indexes, production, type, and functional traits]. Journal of dairy science, 89(6), 2257-2267. doi: 3168/jds.S0022-0302(06)72297-4.

13. Rokouei, M., Vaez Torshizi, R., Moradi Shahrbabak, M., Sargolzaei, M., \& Sørensen, A. C. (2010). [Monitoring inbreeding trends and inbreeding depression for economically important traits of Holstein cattle in Iran]. Journal of Dairy Science, 93 (7), 3294-3302. doi: 10.3168/jds.2009-2748.

14. Guskova, S.V., Turbina, I.S., Eskin, G.V., \& Kombarova, N.A. (2014). Osnovnye geneticheskie prichiny embrionalnykh poter $v$ molochnom skotovodstve, svyazannye $s$ intensivnoy selektsiey po produktivnosti [Underlying causes of embryo losses associated with genetic disorders of highproducing dairy cattle]. Dairy and Beef Cattle Farming, 3, 10-14. [In Russian].

15. Ehjsner, F.F. (1981). Teoriya i praktika molochnogo dela $v$ skotovodstve [The theory and practice of livestock breeding]. Kiev: Urozhaj. [In Russian].

16. Pidpala, T. V. (2005). Porodotvornyi protses ta inbrydynh u molochnomu skotarstvi [Largly scale selection and cultivation on lines]. Animal Breeding and Genetics, 38, 107-110. [In Ukrainian]. 
17. Krasota, V.F., Lobanov, V.T., \& Dzhaparidze, T.G. (1990). Razvedenie selskokhozyaystvennykh zhivotnykh [Breeding of farm animals]. Moscow: Agropromizdat. [In Russian].

18. FAO. The State of the World's Animal Genetic Resources for Food and Agriculture, edited by Barbara Rischkowsky \& Dafydd Pilling. Rome (2007).

19. Borovikov, V. STATISTICA: iskusstvo analiza dannykh na kompyutere [STATISTICA: the art of analyzing data on a computer. For professionals]. SPb.: Piter, 2001. [In Russian].

20. Bjelland, D. W., Weigel, K. A., Vukasinovic, N., \& Nkrumah, J. D., (2013). Evaluation of inbreeding depression in Holstein cattle using whole-genome SNP markers and alternative measures of genomic inbreeding. Journal of dairy science, 96(7), 4697-4706. doi: 10.3168/jds.2012-6435.

21. Bykadorov, P. (2013). Inbrydynh ukrainskoi chorno-riaboi molochnoi khudoby ta hospodarsky korysni oznaky tvaryn [Impact inbreeding to economically valuable trainian Black-Motley Dairy cattle]. Livestock Ukraine, 3, 19-21. [In Ukrainian].

22. Klimova, S. P., Shendakov, A. I. \& Shendakova, T. A. (2012). Vliyanie stepeney inbridinga na molochnuyu produktivnost cherno-pestrogo golshtinizirovannogo skota [Influence of the degrees of inbreeding on the milk productivity of Black-and-White Holstein cattle]. Vestnik Ore/GAU, 4 (12), 8689. [In Russian].

23. Pershuta, V. V. (2011). Vzaiemozviazok rivnia vyroshchuvannia ta molochnoi produktyvnosti korivpervistok [Correlation level cultivation and milk production of cows-firstborn]. Animal Breeding and Genetics, 45, 192-199. [In Ukrainian].

24. Pilát, Z., \& Bouška, J. (1986). Intenzita rûstu a následná užitkovost prvotelek. Živoč, 31(6), 499-506. [in Polish].

25. Pendyuk, A.R., Fedorovych, V.V., \& Mazur, N.P. (2019). Fenotypovyi proiav oznak molochnoi produktyvnosti u koriv riznykh henotypiv ukrainskoi chorno-riaboi molochnoi porody [Phenotype features appearance of dairy productivity of different Ukrainian Dairy Black-and-White breed cows genotypes]. Animal Breeding and Genetics, 58, 33-40. doi: 10.31073/abg.58.05 [In Ukrainian].

26. Koval, T.P. (2017). Buhai-plidnyky ta yikh vplyv na hospodarsky korysni oznaky koriv napivsester za batkom [Bulls and their impact on the economic useful signs cows daughters of polyester father]. Animal Breeding and Genetics, 53, 124-129. doi: 10.31073/abg.53.16 [In Ukrainian].

27. Voitenko, S.L., \& Sydorenko, O.V. (2020). Otsinka buhaiv holshtynskoi porody za molochnoiu produktyvnistiu yikh dochok [Estimation of Holstein breed bulls by dairy productivity of their daughters]. Animal Breeding and Genetics, 59, 26-34. doi: 10.31073/abg.59.03 [In Ukrainian].

28. Iudin V.M., \& Liubimov, A.I. (2015). Opyt ispolzovaniya inbridinga v selektsii molochnogo skota [Native and foreign experience of inbreeding use in dairy cattle selection]. Zootechniya, 8, 6-7. [In Russian].

29. Saksa, E.I., \& Maslennikova, E.S. (2018). Effektivnost ispolzovaniya golshtinskikh bykov, vyvedennykh putem primeneniya razlichnykh stepeney inbridinga [The effectiveness of the use of Holstein bulls, derived by applying various degrees of inbreeding]. Dairy and Beef Cattle Farming, 4, 9-13. doi: 10.25632/MMS.2018.2018.16876. [In Russian].

30. Ivanov, M.F. (1964). Novaya poroda sviney - ukrainskaya stepnaya belaya, vyvedennaya v AskaniiNova, i metody ee obrazovaniya [A new breed of pigs - Ukrainian Steppe White, bred in AskaniaNova, and methods of its education]. Moscow: Kolos, 5, 182-195. [In Russian].

31. Samusenko, A.I. (1986). Polnoe sobranie sochineniy [Simmental cattle]. Kiev: Urozhai. [In Russian].

32. Kislovskii, D.A. (1965). Problema porody i puti ee uluchsheniya [The problem of the breed and ways to improve it. Selected Works]. Moscow: Kolos. [In Russian].

33. Dunin, I.M., Trufanov, V. G., \& Novikov, D. V. (2012). Ispolzovanie inbridinga v molochnom skotovodstve [Inbreeding in dairy cattle-breeding]. Zootekhniia, 9, 2-3. [In Russian].

34. Polupan, Yu.P. (2001). Problemy konsolidatsii riznykh selektsiinykh hrup tvaryn [Problems of consolidation of different selection groups of animals]. Bulletin of Agricultural Science, 12, 42-46. [In Ukrainian]. 